Proceedings of the New Zealand Grassland Association 48: 157.161 (1987)

\title{
SWEET BRIER CONTROL WITH GOATS
}

G.L. HOLGATE and D.A. WEIR

Department of Lands and Survey, Christchurch

Abstract

A grazing trial in Central Otago compared the effectiveness of feral goats, Angora goats and Merino sheep for sweet brier control. The three animal types were set stocked in replicate 0.5 ha paddocks at 10 Angoras, 14 ferals and 12 Merinos per ha. Goats were also rotationally grazed on a 50 ha block at approximately 10 goats per ha. Goat grazing reduced living brier in the trial paddocks to negligible proportions within 2 years whilst sheep grazing had minimal impact. Goat grazing resulted in increased clover content within the sward in trial paddocks. A reduction in brier density was also recorded on the 50 ha block.

Keywords: Angoras, Merinos, white clover

\section{INTRODUCTION}

Sweet brier (Rosa rubiginosa) is a nuisance weed of particular significance in the drier parts of Otago, Canterbury and Marlborough, where it is generally classified as a Class B noxious plant. Bascand and Jowet (1981) estimated that sweet brier was abundant on more than 100,000 ha of farmable land in the South Island. It is common where there is a high level of fertility, a well drained soil, minimum competition, and protection from grazing especially at thevulnerable seedling stage (Molloy 1964). The possibility of using goats to control blackberry was noted as early as 1914 (Fields and Experimental Farm Division). In the last decade renewed interest and research has been focussed on the control of scrubweeds by goats (eg. Clark et al. 1982, Holgate 1983, Radcliffe 1984).

Since 1978 goats have been used for brier control on Merivale Station, Tarras, and the effects on one block have been monitored since 1980. This paper reports on a trial established in 1981 to compare the relative value of feral goats, Angora goats and merino sheep for brier control, and on the monitoring of the block.

\section{MATERIALS AND MATERIALS}

\section{Grazing Trial}

The three animal types were set stocked separately in replicated 0.5 ha paddocks at rates designed to equate the food energy requirements of animals in each paddock. This was done by equating metabolic bodyweights (liveweights 0.73 ) 1 . The stocking rates used were 10 Angoras, 14 ferals and 12 Merinos per ha resulting from average animal liveweights of $47.3 \mathrm{~kg}, 29.7 \mathrm{~kg}$ and $39.8 \mathrm{~kg}$ respectively at the commencement of the trial.

Merinos were young wethers, Angoras mixed-age wethers and the ferals (captured from the wild approximately three years previously) were mixed-age dry females. Independent groups of all three animals were maintained as duplicated treatments randomised in six contiguous paddocks. Animal weights were checked periodically and fleece weights from the Merinos and Angoras were recorded at shearing. Paddocks were spelled whenever animal liveweights declined appreciably, or when the mean pasture height was reduced to a stubble of $<3 \mathrm{~cm}$.

In May 1984 the main part of the trial was completed and all animals were removed from the 0.5 paddocks The paddocks were left ungrazed until May-June

Metabolic bodyweight has been used to obtain proportional measurements of fasting heat production and should equate food energy requirements (Blaxter 1967). 
1985. Two paddocks which had previously been goat treatments were thereafter subject to intermittent intensive grazing by Merino sheep. In October 1985 the remaining two paddocks previously grazed by goats were set stocked with 12 Merino wethers/ha. The two paddocks previously grazed by Merinos were set stocked with a mixture of 12 Merino wethers and 4 Angora wether goats/ha.

\section{Brier Measurements}

Initially each paddock contained scattered brier bushes in a pasture dominated by browntop (Agrostis capillaris) and sweet vernal (Anthoxanthum odoratum). Living plant cover of brier and pasture species was estimated by first hit point analysis and the density of living brier was calculated by the joint point-distance nearest. neighbour distance technique. In each paddock 300 points were sampled for the cover estimates and approximately 2500 brier plants were initially measured amongst the six paddocks for the density determinations. The height and width of plants encountered for the density estimates was also recorded and photographs of marked brier plants in each paddock were taken. A brier plant was defined as "a cane or group of canes separated by more than $10 \mathrm{~cm}$ at ground level from any other cane or group of canes". This overcame the problem of distinguishing separate plants from suckers in the tangle of canes at the base of most bushes.

\section{Farm Block}

A 50 ha block subject to goat grazing was also monitored. The goats were various feral/Angora crosses stocked at approximately 10/ha for about three months in every nine months. The methods used were similar to those employed in the trial, 400 points were analysed for cover estimates and approximately 600 distance measurements were taken and 600 brier plants were measured.

\section{RESULTS AND DISCUSSION}

Trial

Within nine months, ground cover of living brier was reduced by more than $75 \%$ in the goat paddocks, and was significantly lower than that in the sheep paddocks for the rest of the trial (Fig. 1).

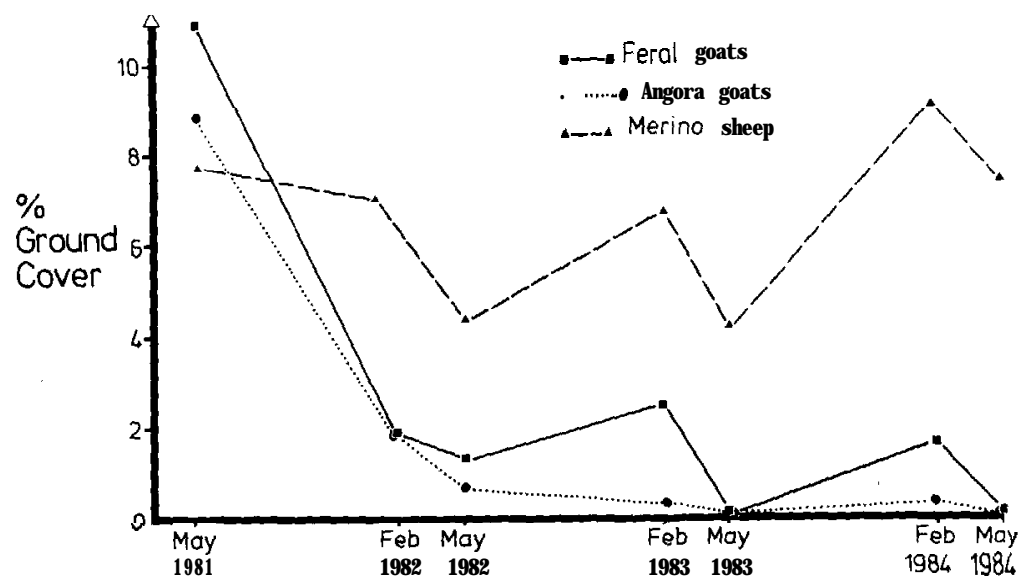

Figure 1: Changes in living sweet brier ground cover. 
Similarly the mean height and width of plants in the goat paddocks were reduced by more than $50 \%$ within nine months, and by almost $90 \%$ within three years (Table 1).

Table 1: Average maximum living size (height $x$ width) of sweet brier plants $\left(\mathrm{cm}^{\prime}\right)$.

\begin{tabular}{lccc}
\hline & & Treatments & \\
& Feral & Angora & Merino \\
\hline May 1981 & 4457 & 3854 & 4080 \\
Feb 1962 & 1063 & 724 & 3398 \\
May 1984 & 65 & 24 & 2963 \\
\hline
\end{tabular}

The goats also reduced the number of living canes per plant. By May 1984 less than $10 \%$ of the plants in the goat paddocks had more than 2 living canes, In the sheep paddocks, and initially in the goat paddocks, $60 \%$ of the plants had more than 2 living canes. Conversely, at the completion of the trial, approximately $1 \%$ of the plants in the goat paddocks consisted of 8 or more living canes, whereas initially some $20 \%$ of the plants consisted of 8 or more living canes.

Goats also reduced the number of living plants. After two years, density of living brier plants under goat treatments was significantly lower than that under sheep (Fig.

2) and remained so for the rest of the trial.

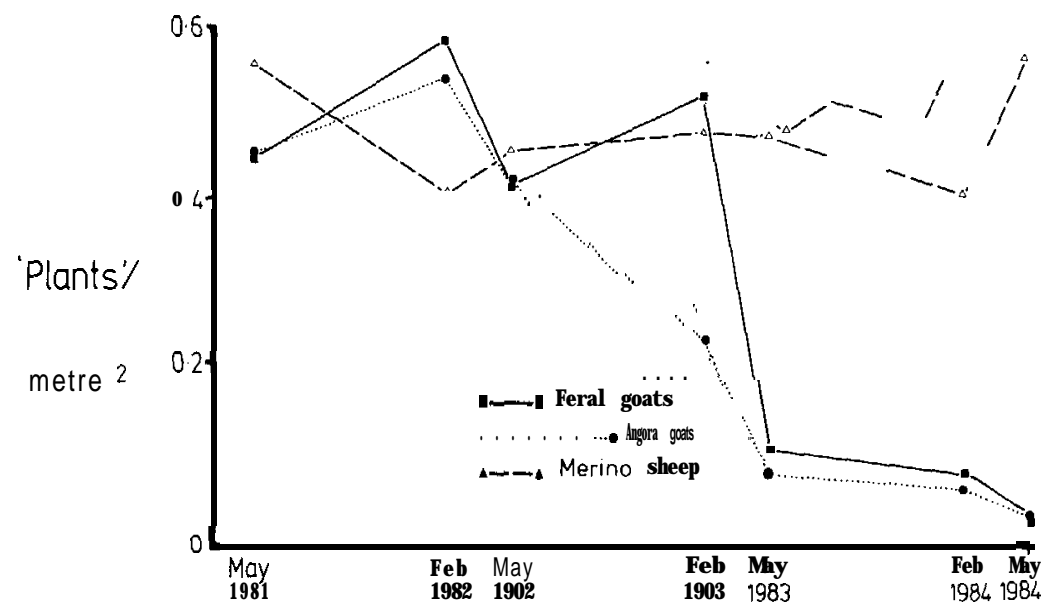

Figure 2: Changes in living sweet brier plant density.

The browsing preference of the goats resulted in an increase in clover cover compared with that under sheep grazing (Fig. 3). This was particularly so for the Angora treatments which had significantly higher clover than the sheep treatments from February 1983 on. Increased clover content in swards grazed by goats has previously been reported by Clark et al. (1982).

Mean fibre production figures recorded from the Merinos and Angoras are presented in Table 2. Angoras were shorn in early spring and autumn while the Merinos were only shorn in early spring. It should be noted that the percentage of time that the animals were in the trial varied between years and between treatments. Clearly however, the data indicates that as well as controlling brier the Angoras were also producing significant quantities of mohair. 


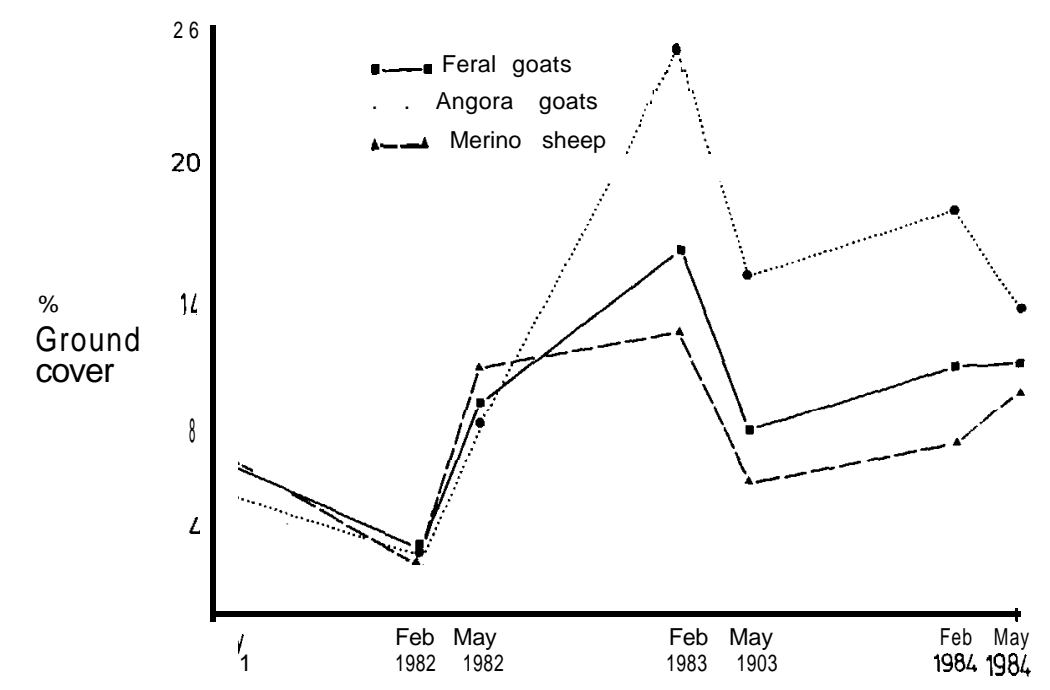

Figure 3: Changes in living clover cover.

Table 2: Mean fibre production from merinos and angoras.

\begin{tabular}{cccc}
\hline & $\begin{array}{c}\text { Merinos } \\
\text { kg/animal }\end{array}$ & $\begin{array}{c}\text { Angoras } \\
\text { kg/animal }\end{array}$ & \\
\hline 1981 & 4.3 & 1.4 & \\
1982 & 3.4 & 1.9 & \\
1983 & 4.2 & 2.1 & 'One shear only \\
1984 & - & 1.3 & ' \\
\hline
\end{tabular}

Table 3: Comparison of sweet brier density and size (height $x$ width) where grazing treatments have been altered.

\begin{tabular}{|c|c|c|c|c|c|c|}
\hline \multirow[b]{2}{*}{$\begin{array}{l}\text { Treatment } \\
\text { Feb } 1964\end{array}$} & \multicolumn{3}{|c|}{ Density (plants $/ \mathrm{m}^{*}$ ) } & \multicolumn{3}{|c|}{ Plant Size $\left(\mathrm{cm}^{2}\right)$} \\
\hline & $\begin{array}{l}\text { Goats } \\
0.040\end{array}$ & $\begin{array}{l}\text { Merino } \\
0.405\end{array}$ & $\begin{array}{l}\text { Goats } \\
0.100\end{array}$ & $\begin{array}{l}\text { Goats } \\
102\end{array}$ & $\begin{array}{l}\text { Merino } \\
4351\end{array}$ & $\begin{array}{l}\text { Goats } \\
48\end{array}$ \\
\hline Treatment & $\begin{array}{l}\text { Casual } \\
\text { Merino }\end{array}$ & $\begin{array}{l}\text { Merino/ } \\
\text { Goats }\end{array}$ & Merino & $\begin{array}{l}\text { Casual } \\
\text { Merino }\end{array}$ & $\begin{array}{l}\text { Merinol } \\
\text { Goats }\end{array}$ & Merino \\
\hline Feb 1986 & 0.025 & 0.565 & 0.010 & 157 & 3499 & 187 \\
\hline Maximum Error & \pm 0.04 & \pm 0.38 & \pm 0.09 & & & \\
\hline
\end{tabular}

Since grazing treatments were altered no significant change in brier density has been recorded (Table 3). The paddocks now containing the goat/sheep mix have shown a reduction in average plant size. Where sheep treatments have replaced goat treatments, an increase in mean plant size has resulted from the continued growth of a small number of large plants (Table 3 ).

Farm Block

Data on the cover of brier and stature of plants from this block are very similar to that from the trial, ie there was a dramatic decrease in cover and size of brier plants within one year. The length of time taken to register a decrease in plant density is the obvious difference between the trial and the farm block (Fig. 4).

The longer response time, in terms of a decrease in plant density, is most likely attributable to the lower stocking rate, and longer and more frequent spelling 


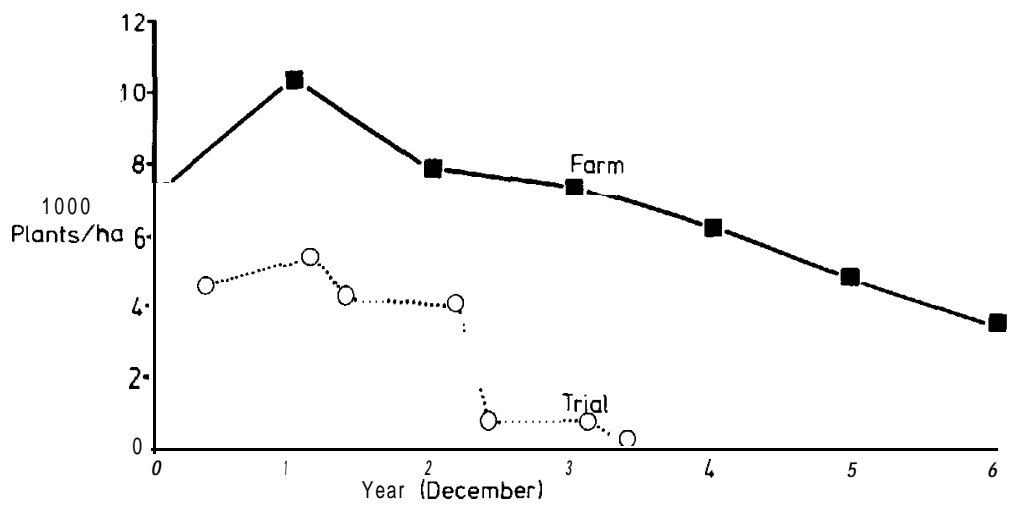

Figure 4: Changes in sweet brier plant density - trial (mean of both goat treatments) and farm block.

periods. The initial increase in the number of plants in the first year for both the trial and farm block may in large part be due to the counting of extra separate plants following the opening up of large brier bushes by goats.

The results show that goats can control brier. They readily browse brier and can dramatically reduce the stature of bushes and reduce the number of plants. Control of any shrub weed is aided by intensive farming systems with adequate subdivision and high stocking rate, and control of brier with goats is no exception. At lower stocking rates, goats may be used to harvest brier on a sustainable basis and, in mixed flocks with sheep, this may increase total animal production.

\section{Acknowledgements}

The trial was a co-operative one with capital costs shared with Merivale Station, Tarras. The authors acknowledge the hospitality and full co-operation of Gerald and Mary Goodger of Merivale Station and the technical assistance of Carol Jensen, Alice Shanks and David Payton.

\section{References}

Sascand L.D., Jowett G.H. 1981. Scrubweed cover of South Island agricultural and pastoral land. NZ Journal of Experimental Agriculture 9: 307.327.

Blaxter K.L. 1967. The energy metabolism of ruminants, revised ed. London. Hutchinson 332 p.

Clark D.A., Lambert M.G., Rolston M.P., Dymock N. 1982. Diet selection by goats and sheep on hill country. Proceedings NZ Society of Animal Production 42: 155-157.

Fields and Experimental Farms Division, 1914. Answers to correspondents. Goats and blackberry. NZ Journa/of Agriculture 9(3): 219.

Holgate G.L. 1983. Goats for shrub-weed control. Mohair Producers Association of NZ (/nc). AGM 1983 Seminar speeches.

Moiloy S.P.J. 1964. Sweet Brier - A Vigorous Woody Weed in the South Island Tussock Grassland. NZ Journal of Agriculture 109: 105-108.

Radcliffe J.E. 1984. Gorse control with goats. Proceedings NZ Grass/and Association 45: 152-159. 